\title{
Erfaringer fra en kronisk syk pasient
}

\author{
Jeg har vært kronisk syk lenge. Det \\ tok ca. 20 år før legene fant frem \\ til riktig diagnose, i mitt tilfelle \\ astma. I disse 20 årene har jeg hatt \\ store problemer.
}

Jeg ble et mobbeoffer og ble sett på som en lat og utspekulert utnytter av trygdesystemet. Dette skapte store problemer for meg, og angsten og depresjonen kom snikende. Det førte igjen til flere sykmeldinger og mer fravær fra jobben. I denne perioden hadde jeg ca. 100 sykehusinnleggelser. Som 55-åring ble jeg uføretrygdet.

Da ble plutselig tiden lang. Jeg hadde jo tross alt vært en aktiv mann selv om jeg var syk. Jeg tenkte mye på at nå hadde ingen bruk for meg lenger. Det jeg etter en tid savnet, var innspill fra leger og den øvrige helsetjenesten om hva de kunne tilby.

I ettertid spør jeg meg selv, etter så mange sykehusinnleggelser, hvorforingen innen helsetjenesten tok seg tid og spurte hvordan jeg levde hjemme, for eksempel med hensyn til medisinbruken. Her lå nemlig mange av mine problemer. Jeg hadde ikke fått god nok opplæring i bruk av medisiner og valgte å slutte med dem da jeg følte meg i form.

Som foredragsholder for både ansatte i helsetjenesten og pasienter har jeg fått bekreftet at mange pasienter velger å slutte med medisiner når de føler seg bedre. Resultatet er da ofte nye sykehusinnleggelser. Jeg savner kvalitetskontroll og kommunikasjon. Det må sjekkes om pasientene har forstått opplæringen i for eksempel bruk av medisiner. Vi må tore å spørre hverandre! På Lærings- og mestringssenteret på Aker sykehus i Oslo lærte jeg mye om lagspill mellom helsepersonell, pasienter og pårørende. Resultatet blir bra hvis alle parter får informasjon, kunnskap og bistand til å håndtere langvarig sykdom og helseforandringer. Målet må jo være at vi som brukere skal få utvidet innsikt om egen situasjon, bli styrket i vår mestring av hverdagen og slippe flest mulig sykehusinnleggelser. Formelen er: God informasjon $\rightarrow$ lagspill $\rightarrow$ bedre livskvalitet $\rightarrow$ færre innleggelser $\rightarrow$ bedre liv for pasient og pårørende.

Kanskje vurderer jeg legene feil, men jeg har erfart at de lett blir fiksert på en diagnose og glemmer helheten. Det virker som om det er lett å glemme at jeg er astmatiker når annet står på. Da jeg for eksempel ble lagt inn på sykehus med nyrestein, glemte de at jeg brukte astmamedisiner, til tross for at det sto i journalen. Jeg spør da: Hva skjer den dagen jeg ikke kan gjøre rede for meg? Slike skremmende opplevelser har ført til at jeg har skrevet en minijournal med relevante opplysninger og de siste epikrisene. Dette har jeg alltid med meg, og min kone og mine barn har også et eksemplar. Den legges alltid frem når jeg kommer til en ny lege eller havner på akutten på et sykehus. Jeg har fått gode tilbakemeldinger fra helsepersonell på dette tiltaket. Det sparer tid, og jeg som pasient blir spart for mange spørsmål.

Målet bør også være tillit til legene, noe som vil være en god gevinst for begge parter og kanskje gi færre legebesøk. I årevis har jeg lett etter informasjon om trygderettigheter i den norske folketrygden og ikke minst rehabiliteringstilbud. På denne måten har jeg fått mange ideer om hvordan ting kan bli bedre, og jeg har bygd opp et rikholdig arsenal av gode råd for mestring av dagliglivets utfordringer. I ca. 30 år jobbet jeg med salg og markedsføring. Videre har jeg arrangert turer for både eldre og handikappede. Denne bakgrunnen har lært meg å lytte til og forstå andre. Noen kronikere tør ikke spørre om hjelp, og de tar heller problemene med seg hjem. Her ser vi igjen hvor viktig lagspill er. Alle må med. Jeg har holdt foredrag for sykepleierstudenter, og nå ønsker jeg sterkt å komme i kontakt med legestudenter.

Mitt budskap er at kronikerne må tas på alvor og lyttes til. Deretter må det settes opp mål i samarbeid med lege, fysioterapeut og øvrig helsepersonell. Man kan leve et godt liv med en kronisk diagnose, men det krever åpenhet og god informasjon. For de som trenger hjelp, finnes den, blant annet på Glitreklinikken, Granheim lungesykehus og Røros Rehabilitering. Dette er steder hvor brukeren lærer å takle sykdommen og hverdagen. Tilbakemeldinger som jeg får, bekrefter at et stort flertall aldri har hørt om at slike tilbud finnes.

Selv ønsker jeg å lære mer om det å være kroniker. For da kan jeg spre min kunnskap videre via foredrag. For vi blir aldri utlært!

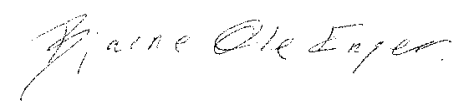

